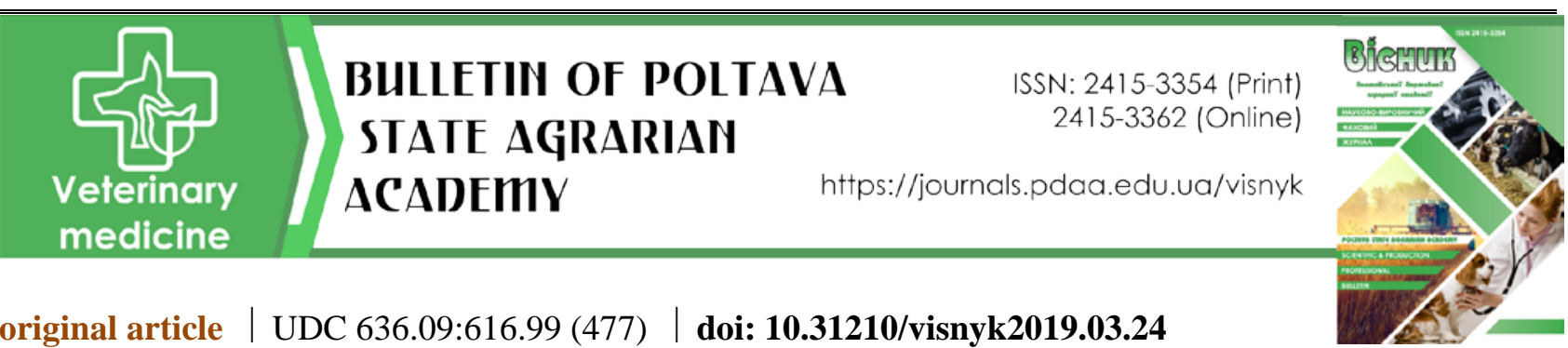

PECULIARITIES OF DOG TOXASCAROSIS SPREADING IN THE TOWN OF POLTAVA

V. O. Yevstafieva, ORCID ID 0000-0003-4809-2584,E-mail: evstva@ukr.net,

B. Yu. Golofayev,

Poltava State Agrarian Academy, 1/3, H. Skovorody Str., Poltava, 36003, Ukraine

At present dog breeding is becoming important in different branches of the economy. The requirements in the development of utility, decorative, sports, and special dog breeding are increasing, because these animals are indispensable assistants of people. There are a lot of various forms of using dogs in the world, one of which is to enrich the human spiritual experience. Besides, dogs are used in protecting economic and other objects, defending state borders. The interest in dog breeding leads to gathering a great number of dogs on a limited territory, and common walking dogs results in considerable spreading of invasion diseases, in particular, animal digestive tract nematodoses. Dog toxascarosis is considered by scholars to be one of the most widely spread dog helminthoses. The research was conducted in the laboratory of the Department of parasitology and veterinary-sanitary expert examination at Poltava State Agrarian Academy. The aim of the investigation was to study the peculiarities of spreading dog toxascarosis in the town of Poltava taking into account the dependence of infestation indices on the age of animals, and also the peculiarities of the disease course in case of dog digestive tract mixed invasions. As a result of coproscopical examination it was established that dog toxascarosis is a spread invasion on the territory of Poltava, and its average prevalence is $31.25 \%$. It was found out that dog toxascarosis mainly takes its course as mono-invasion (75\%). Mixed invasions were revealed in $25 \%$ of animals suffering from toxascarosis, where Toxascaris leonina were found together with intestinal nematodes of Trichuris vulpis, Uncinaria stenocephala species and protozoa of Isospora canis species. Two-component mixed invasions were revealed in $70 \%$ and three-component - in $30 \%$ of cases. Most often dog toxascarosis-trichurosis associated invasion was diagnosed ( $40 \%$ of the total number of the dogs suffering from mixed invasion). More rarely toxascarosis-uncinariosis (20\%), toxascarosis-trichurosis-uncinariosis (20\%), toxascarosis-isosporosis, and toxascarosis-trichurosis-isosporosis associated invasions (each $10 \%$ respectively) were found. It was determined that toxascarosis invasion prevalence indices depend on the age of dogs. So, young dogs aged from 6 to 12 months were infested with T. leonina most of all, where average prevalence reached $46.51 \%$. The lowest prevalence indices were registered in dogs older than five years (16.67\%). The obtained results of the research will enable to increase the effectiveness of conducting treatment and prevention measures in case of dog toxascarosis taking into account the peculiarities of the course and dynamics of the invasion.

Key words: toxascarosis, dogs, spreading, mixed invasions, age dynamics.

\title{
ОСОБЛИВОСТІ ПОШИРЕННЯ ТОКСАСКАРОЗУ СОБАК У МІСТІ ПОЛТАВІ
}

\author{
В. О. Свстаф'єва, Б. Ю. Голофаєв,
}

Полтавська державна аграрна академія, вул. Г. Сковороди, 1/3, м. Полтава, 36003, Україна

Собаківництво наразі набуває важливого значення в різних галузях народного господарства. Потреби в розвитку службового, декоративного, спортивного та спеціального собаківництвва зростаютьь, оскільки ці тварини - незамінні помічники людини. В усьому світі існує безліч різноманітних форм використання собак, одна з них - збагачення духовного світу людей. До того ж собаки беруть участь в охороні народногосподарських та інших об'єктів, зокрема державного кордону. Захоплення собаківництвом у містах призводить до скупчення великої кількості тварин на обмеженій терито- 


\title{
ВЕТЕРИНАРНА МЕДИЦИНА
}

рії, а спільний вигул собак призводить до значного поширення інвазійних захворювань, зокрема нематодозів травного каналу тварин. До одного з найбільш поширеного гельмінтозу собак науковиі відносять токсаскароз. Дослідження виконували на базі лабораторії кафедри паразитології та ветеринарно-санітарної експертизи Полтавської державної аграрної академії. Метою досліджень було вивчити особливості поширення токсаскарозу собак в умовах міста Полтави з урахуванням залежності показників інвазованості від віку тварин, а також особливостей перебігу хвороби у складі мікстінвазій травного каналу собак. За результатами копроскопічних досліджень встановлено, що токсаскароз собак є поширеною інвазією на території міста Полтави, середня екстенсивність інвазії становить 31,25\%. 3'ясовано, що токсаскароз у собак переважно перебігає у вигляді моноінвазіі (75\%). Мікстінвазії виявляли у $25 \%$ хворих на токсаскароз тварин, де Toхаscaris leonina виявляли разом із кишковими нематодами видів Trichuris vulpis, Uncinaria stenocephala та найпростішими організмами виду Isospora canis. У 70 \% випадків встановлено двокомпонентні мікстінвазії, у $30 \%$ трикомпонентні. Найчастіше в собак діагностували токсаскарозно-трихурозну асоиіативну інвазію (40\% від загальної кількості хворих на мікстінвазії собак). Рідше виявляли токсаскарозноунцинаріозну (20\%), токсаскарозно-трихурозно-унцинаріозну (20\%), токсаскарозно-ізоспорозну та токсаскарозно-трихурозно-ізоспорозну асочіативні інвазії (по $10 \%$ відповідно). Визначено, що показники екстенсивності токсаскарозної інвазії залежать від віку собак. Найбільш інвазованим T. lеопіпа був молодняк віком від 6 до 12 місяиів, де середня екстенсивність інвазії сягала 46,51\%. Найнижчі показники екстенсивності інвазії реєстрували ву собак старших п'ятирічного віку (16,67 \%). Отримані результати досліджень дозволять підвищити ефективність проведення лікувальних та профілактичних заходів за умови токсаскарозу собак з урахуванням особливостей перебігу та вікової динаміки інвазії.

Ключові слова: токсаскароз, собаки, поширення, мікстінвазії, вікова динаміка.

\section{ОСОБЕННОСТИ РАСПРОСТРАНЕНИЯ ТОКСАСКАРОЗА СОБАК В ГОРОДЕ ПОЛТАВЕ}

\author{
В. А. Евстафьева, Б. Ю. Голофаев, \\ Полтавская государственная аграрная академия, ул. Г. Сковороды, 1/3, г. Полтава, 36003, Украина
}

В статье представлены результаты исследований по изучению особенностей распространения токсасакроза собак на территории города Полтавы. Установлено, что средняя пораженность собак возбудителем токсаскароза составляет 31,25 \%. У собак инвазия преимущественно протекает в виде моноинвазии (75\%). Микстинвазии диагностировали в $25 \%$ случаях, где Toxascaris leonina выделяли вместе с кишечными нематодами видов Trichuris vulpis, Uncinaria stenocephala и простейшими организмами вида Isospora canis. B $70 \%$ случаев установлено двухкомпонентные микстинвазии, в 30 \% - трехкомпонентные. Установлено, что показатели экстенсивности инвазии зависят от возраста собак. Так, наиболее инвазированным T. lеопіпа был молодняк в возрасте от 6 до 12 месяцев, где средняя экстенсивность инвазии достигала 46,51\%.

Ключевые слова: токсасакроз, собаки, распространение, микстинвазии, возрастная динамика.

Вступ

Соціально-економічні та геополітичні зміни в різних країнах світу, зокрема в Україні, призвели до різкого зростання використання собак у різних галузях. Це - застосування можливостей собак на кордоні, після катастроф, землетрусів, вибухів, пошук наркотиків, зброї тощо. 3'явилися нові спеціальності - заводчики, кінологи, дресирувальники. Усе зазначене сприяє зростанню чисельності собак у мегаполісах, містах, селищах та інших сільських населених пунктах. У різних державних структурах утворилися цілі підрозділи, які займаються розведенням собак та їхнім дресируванням. Дуже багато громадян утримують у квартирах собак. При цьому багато хто не дотримується елементарних норм гігієни, санітарії. Більшість власників собак не перевіряють своїх чотирилапих на гельмінтози, обмежуються лише вакцинацією проти інфекційних хвороб. При цьому не звертається увага на зараженість собак збудниками паразитарних хвороб. Зокрема нематодозами травного каналу [1-5].

Одним з найбільш поширених збудників гельмінтозів у домашніх непродуктивних тварин є нематоди Toxascaris leonina з родини Ascaridae. Личинки T. leonina проходять тканинну фазу розвитку в товщі стінки кишечника, що і визначає характер морфофункціональних змін з боку органів та систем м'ясоїдних в умовах цієї інвазії. Водночас у природних умовах у собак часто реєструється мікстінва- 


\section{ВЕТЕРИНАРНА МЕДИЦИНА}

зія декількома видами гельмінтів та найпростіших організмів. Відомо, що за наявності мікстінвазіі в організмі хазяїна виникають більш глибокі зміни функцій органів і систем [6-10].

У дослідженнях вітчизняних і зарубіжних авторів токсаскароз зареєстровано в собак на території багатьох країн світу, зокрема в Україні. Екстенсивність інвазії собак T. leonina на території Словацької Республіки становила 7,3\%, Мексики $-5,5 \%$, Болгарії - 2,5\%, Ірану $-6 \%$, Туреччини - $15 \%$, Зімбабве - 1,6 \% [11-16].

На території східної частини України вітчизняними науковцями при дослідженні собак було зареєстровано 9 видів гельмінтів, одним з яких є Toxascaris leonina (von Linstow, 1902). Причому екстенсивність гельмінтозної інвазії у собак, що утримувались індивідуально у квартирах, була $39,2 \%$, в умовах розплідника службового собаківництва - від 19,6 до 32,7 \% [17]. Водночас на території Полтавської області паразитофауна собак представлена 8 збудниками гельмінтозів, де екстенсивність інвазії собак токсаскарисами становила 15,15 \%, а інтенсивність інвазії коливалася в межах від 13,17 до 16,54 екз. яєць у 1 краплі досліджуваної рідини [18].

Зважаючи на вищенаведене, метою наших досліджень було вивчити особливості поширення токсаскарозу собак в умовах міста Полтави. Для досягнення мети необхідно розв'язати наступні задачі: встановити показники інвазованості собак різних вікових груп Toxascaris leonina; визначити особливості перебігу токсаскарозу у складі нематодозів та протозоозів травного каналу тварин.

\section{Матеріали і методи досліджень}

Роботу виконували упродовж 2018-2019 рр. в умовах лабораторії кафедри паразитології та ветеринарно-санітарної експертизи Полтавської державної аграрної академії.

Вивчення поширення токсаскарозу та інших кишкових інвазій собак у місті Полтаві здійснювали за результатами копроскопічного дослідження тварин, які надходили до лабораторії. Усього досліджено 128 собак різних вікових груп (до 6 міс., 6-12 міс., 1-5 р. та старші 5 р.). При паразитологічному обстеженні собак основними показниками ураження тварин збудниками гельмінтозів та протозоозів були екстенсивність та інтенсивність інвазії (EI та II). Гельмінтоовоскопію проб фекалій проводили за методом Котельникова-Хренова [19].

Визначення видової належності яєць гельмінтів та найпростіших організмів проводили за допомогою атласів диференціальної діагностики гельмінтозів та протозоозів тварин [20, 21].

\section{Результати досліджень та їх обговорення}

За результатами проведених досліджень встановлено, що токсаскароз є поширеною інвазією собак різних вікових груп на території міста Полтави. Середня екстенсивність інвазії становила 31,25\% за наявності інтенсивності інвазії - від 3 до 47 яєць у трьох краплинах флотаційної рідини. Водночас виявлено, що токсаскароз переважно перебігає у вигляді моноінвазії - 75 \%. Мікстінвазії виявляли у 25 \% хворих на токсаскароз собак (рис. 1).

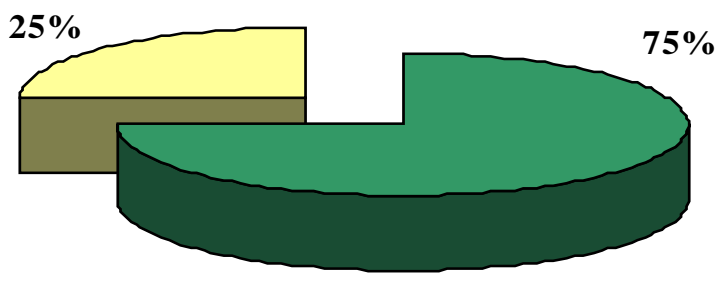

Моноінвазія T.leonina

Мікстінвазії

\section{Рис. 1. Відсоткове співвідношення моно- та мікстінвазій собак за токсаскарозу}

Toxascaris leonina за умови асоціативного перебігу виявляли разом із нематодами видів Trichuris vulpis, Uncinaria stenocephala та найпростішими організмами виду Isospora canis. Частіше виявляли двокомпонентні мікстінвазії - у 70 \% від загальної кількості хворих на мікстінвазії собак. У 30 \% випадках виявляли трикомпонентні мікстінвазії (рис. 2). 


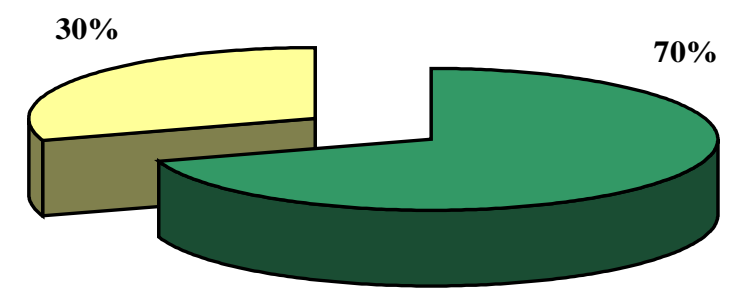

двокомпонентні $\square$ трикомпонентні

\section{Рис. 2. Відсоткове співвідношення дво- та трикомпонентних мікстінвазій за токсаскарозу собак}

Найчастіше у собак діагностували токсаскарозно-трихурозну інвазію (40 \%). Рідше виявляли токсаскарозно-унцинаріозну $(20 \%)$, токсаскарозно-трихурозно-унцинаріозну $(20 \%)$, токсаскарозноізоспорозну (10 \%) та токсаскарозно-трихурозно-ізоспорозну асоціативні інвазії (10\%) (рис. 3).

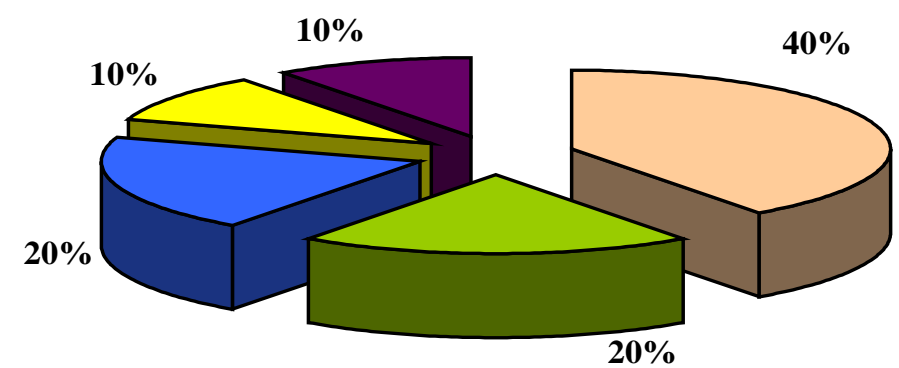

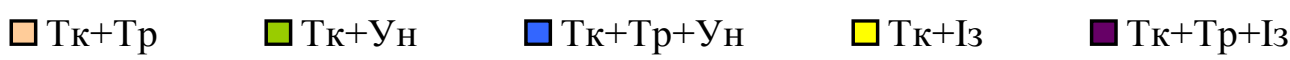

Рис. З. Особливості перебігу токсаскарозу собак у складі мікстінвазій:

Тк-токсаскароз, Тр-трихуроз, УН-унцинаріоз, Із - ізоспороз

За результатами проведених досліджень встановлено, що показники екстенсивності токсаскарозної інвазії залежать від віку собак (рис. 4).

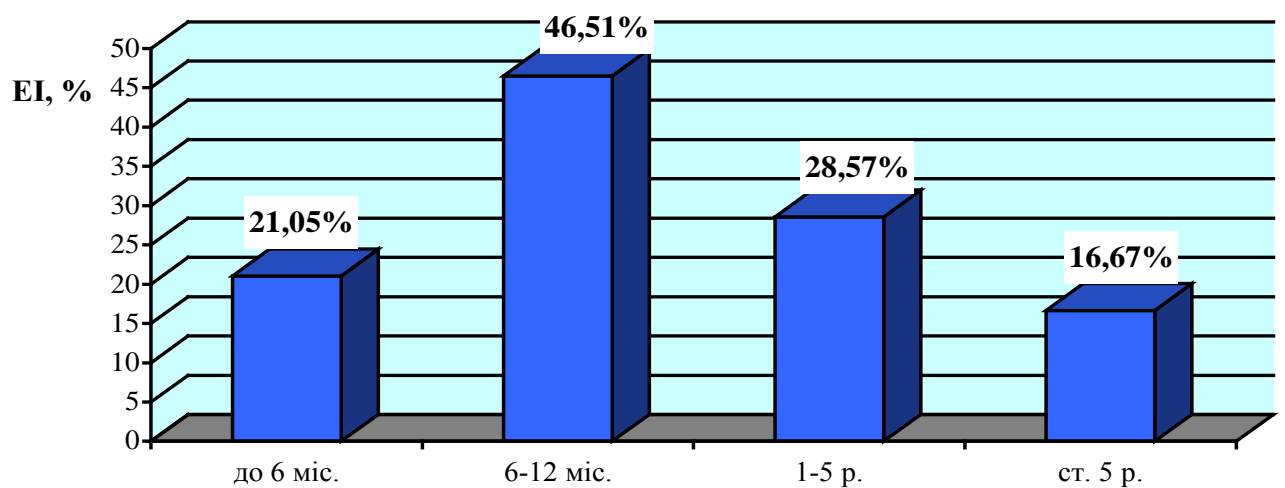

Рис. 4. Вікова динаміка токсаскарозу собак

Хоча токсаскароз діагностували в собак будь-якого віку, однак найбільш інвазованим T. leonina виявився молодняк віком від 6 до 12 місяців, де середня екстенсивність інвазії сягала 46,51\%. Менш інвазованими були цуценята до 6-місячного віку (EI - 21,05 \%) та собаки віком від одного до п’яти років (EI - 28,57 \%). Найменш ураженими виявилися собаки старші 5 річного віку, середня екстенси- 


\section{ВЕТЕРИНАРНА МЕДИЦИНА}

вність інвазії становила 16,67 \%.

Згідно з літературними даними токсаскароз собак є однією з поширених нематодозів травного каналу тварин в Україні, особливо в містах, де відбувається зосередження великої кількості різних собак (домашніх, безпритульних, породистих, безпорідних). Причому показники інвазованості тварин можуть коливатися в межах від 5,4 до $15,15 \%$ [18, 22]. Водночас за результатами власних досліджень середня інвазованість собак на території міста Полтави становила $31,25 \%$. На нашу думку, таке розповсюдження збудника інвазії пов'язане із відсутністю профілактичних дегельмінтизацій та діагностичних досліджень тварин. Також нами виявлено, що токсаскароз може перебігати у вигляді мікстінвазій разом із збудниками інвазійних захворювань кишкового каналу - T. vulpis, U. stenocephala, I. canis. Про асоціативний перебіг гельмінтів свідчать і результати досліджень інших науковців [14, 16]. Одночасно з'ясовано, що вікова динаміка токсаскарозу собак характеризується найбільшою сприйнятливістю молодняка віком від 6 до 12 місяців до збудника інвазії. В подальшому з віком собак показники екстенсивності інвазії поступово знижуються, що, на нашу думку, пов'язано із формуванням вікового імунітету.

\section{Висновки}

Встановлено, що токсаскароз $є$ поширеною нематодозною інвазією собак на території міста Полтави, де середня екстенсивність інвазії становить $31,25 \%$. 3'ясовано, що Toxascaris leonina в організмі собак частіше паразитує у вигляді моноінвазії (75\%), рідше - у вигляді мікстінвазій (25\%) разом iз збудниками інвазійних хвороб кишкового каналу тварин, а саме: Trichuris vulpis (до $70 \%$ ), Uncinaria stenocephala (до 40 \%) та Isospora canis (до 20 \%). Виявлено залежність показників інвазованості собак T. leonina від їхнього віку. Найбільш ураженим виявився молодняк віком від 6 до 12 місяців, середня екстенсивність інвазії становить 46,51 \%.

Перспективи подальщих досліджень. У подальших дослідженнях планується вивчити ефективність сучасних антигельмінтних препаратів за наявності токсаскарозу собак.

\section{References}

1. Bovenkerk, B. \& Nijland, H. J. (2017). The Pedigree Dog Breeding Debate in Ethics and Practice: Beyond Welfare Arguments. Journal of Agricultural and Environmental Ethics, 30 (3), 387-412. doi: 10.1007/s10806-017-9673-8.

2. Bespalova, N. S. (2003). Uchastie domashnej sobaki v jepizootologii rjada gelmintozov v uslovijah goroda. Veterinarija, 1, 31-33 [In Russian].

3. Furth, M., Hoida, G. \& el-On, J. (1990). Prevalence of helminths in dogs in the Hadera district of Israel. Israel Journal of Medical Sciences, 26 (11), 636-637.

4. Kim, J., Williams, F. J., Dreger, D. L., Plassais, J., Davis, B. W., Parker, H. G. \& Ostrander, E. A. (2018). Genetic selection of athletic success in sport-hunting dogs. PNAS, 115 (30), 7212-7221. doi: 10.1073/pnas.1800455115.

5. Wyckliff, N., Kitaa, J., Thaiyah, A., Maingi, N., Muriuki, J. B. \& Chepkirui, E. (2017). Coprological Study to Determine the Prevalence of Intestinal Helminthes in Dogs of Nairobi, Kenya - A Potential Zoonotic Threat. International Journal of Veterinary Science and Research, 3(1), 025-029. doi: 10.17352/ijvsr.000019.

6. Kim, Y. H. \& Huh, S. (2005). Prevalence of Toxocara canis, Toxascaris leonina and Dirofilaria immitis in dogs in Chuncheon, Korea (2004). Korean Journal of Parasitology, 43 (2), 65-67. doi: 10.3347/kjp.2005.43.2.65.

7. Paquet-Durand, I., Hernández, J., Dolz, G., Zuñiga, J. J., Schnieder, T. \& Epe, C. (2007). Prevalence of Toxocara spp., Toxascaris leonina and ancylostomidae in public parks and beaches in different climate zones of Costa Rica. Acta Tropica, 104 (1), 30-7. doi: 10.1016/j.actatropica.2007.06.011.

8. Esaulova, N. V. (2000). Gelmintozy sobak i koshek, opasnye dlja cheloveka i ih diagnostika. Veterinarija, 6, 22-29 [In Russian].

9. Sivkova, T. N. (2011). Hronicheskaja fetoplacentarnaja nedostatochnost kak sledstvie invazii u plotojadnyh zhivotnyh. Veterinarnyj Vrach, 2, 45-47 [In Russian].

10. Ruiz de Ybáñez, M. R., Garijo, M. M. \& Alonso, F. D. (2001). Prevalence and viability of eggs of Toxocara spp. and Toxascaris leonina in public parks in eastern Spain. Journal of Helminthology, 75 (2), 169-173. doi: 10.1079/joh200164.

11. Szabováeva, E., Miterpáková, J. M., Antolová, D., Papajová, I. \& Šefčíková, H. (2007). Prevalence of 


\section{BETЕРИНАРНА МЕДИЦИНА}

important zoonotic parasites in dog populations from the Slovak Republic. Helminthologia, 44 (4), 170-176. doi: 10.2478/s11687-007-0027-3.

12. Lopez, G., Alvarez-Centeno, P., Cueto-Gonzalez, S., Monge-Navarro, F., Tinoco-Gracia, L., NuñezCastro, K., Perez-Ortiz, P., Medina-Basulto, G., Tamayo-Sosa, A., \& Gomez-Gomez, S. (2017). Prevalence and distribution of intestinal parasites in stray dogs in the northwest area of Mexico. Austral Journal of Veterinary Sciences, 49 (2), 105-111. doi: 10.4067/S0719-81322017000200105.

13. Radev, V., Lalkovski, N., Zhelyazkov, P., Kostova, T., Sabev, P., Nedelchev, N. \& Vas-sileva, R. (2016). Prevalence of gastrointestinal parasites and Dirofilaria spp. in stray dogs from some regions in Bulgaria. Bulgarian Journal of Veterinary Medicine, 19 (1), 57-62. doi: 10.15547/bjvm.872.

14. Kamrani, A. R., Sardari, K. \& Razmi, G. R. (2006). Prevalence of Echinococcus granulosus and other intestinal helminths of stray dogs in Mashhad area, Iran. Archives of Razi Institute, 61 (3), 143-148. doi: 10.22092/ari.2006.103794.

15. Öge, S., Öge, H., Gönenç, B., Özbakış-Beceriklisoy, G. \& Yildiz, C. (2013). Presence of Toxocara eggs on the hair of dogs and cats. Ankara Üniversitesi Veteriner Fakültesi Dergisi, 60, 171-176. doi: 10.1501/Vetfak_0000002573.

16. Davidson, A.-K., Bhikha, K., Vassilev, G. D. \& Dhliwayo, S. (2017). Prevalence of intestinal helminth parasites in stray dogs in urban Harare and selected rural areas in Zimbabwe. Zimbabwe Veterinary Journal, 35 (2), 1-7.

17. Shehovcov, V. S., Mashkej, Y. A., Myshhenko, A. A., Pryhodko, Ju. A. \&. Lucenko, L. Y. (1997). Widowoj coctaw parasitow domaschnich zhiwotnych. Problemy veterynarnogo obslugovuvannja dribnyh domashnih tvaryn, Materialy II mizhnarodnoii naukovo-praktychnoii konferenciii. Kyiv [in Russian].

18. Klymenko, O. S. (2011). Analiz epizootologichnoii sytuaciii shhodo gelmintoziv sobak u pryvatnyh gospodarstvah Poltavskoii oblasti. Visnyk Poltavskoi Derzhavnoi Agrarnoi Akademii, 3, 127-129 [In Ukrainian].

19. Kotelnikov, G. A. (1983). Gelmintologicheskie issledovanija zhivotnyh i okruzhajushhej sredy. Moskva: Kolos [In Russian].

20. Cherepanov, A. A., Moskvin, A. S., Kotelnikov, G. A. \& Hrenov, V. M. (1999). Atlas. Differencialnaja diagnostika gelmintozov po morfologicheskoj strukture jaic i lichinok vozbuditelej. Moskva: Kolos [In Russian].

21. Manzhos, O. F. \& Panikar, I. I. (2006). Veterynarna protozoologija. Doneck [In Ukrainian].

22. Lucenko, L. I., Pavlenko, S. V., \& Ponomarenko, A. M. (2003). Osoblyvosti epizootologii gelmintoziv u sobak v umovah m. Harkova. Veterynarna Medycyna: Mizhvidomchyj Tematychnyj Naukovyj Zbirnyk, 81, 198-202.

\section{Стаття надійшла до редакції 03.09.2019 р.}

Бібліографічний опис для цитування:

Євстаф'єва В. О., Голофаєв Б. Ю. Особливості поширення токсаскарозу собак у місті Полтава. Вісник ПДАА. 2019. № 3. С. 181-186.

(C) Свстаф'єва Валентина Олександрівна, Голофаєв Богдан Юрійович, 2019 